\title{
Sorafenib inhibits therapeutic induction of necroptosis in acute leukemia cells
}

\author{
Friederike Feldmann $^{1,2,3}$, Barbara Schenk ${ }^{1}$, Sofie Martens ${ }^{4,5}$, Peter Vandenabeele , $^{4,5}$ \\ and Simone Fulda ${ }^{1,2,3}$ \\ ${ }^{1}$ Institute for Experimental Cancer Research in Pediatrics, Goethe-University, Frankfurt, Germany \\ ${ }^{2}$ German Cancer Consortium (DKTK), Partner Site, Frankfurt, Germany \\ ${ }^{3}$ German Cancer Research Center (DKFZ), Heidelberg, Germany \\ ${ }^{4}$ Inflammation Research Center, VIB, Ghent, Belgium \\ ${ }^{5}$ Department of Biomedical Molecular Biology, Ghent University, Ghent, Belgium
}

Correspondence to: Simone Fulda, email: simone.fulda@kgu.de

Keywords: necroptosis, cell death, Sorafenib, Smac, leukemia

Received: June 09, $2017 \quad$ Accepted: July 25, $2017 \quad$ Published: August 04, 2017

Copyright: Feldmann et al. This is an open-access article distributed under the terms of the Creative Commons Attribution License 3.0 (CC BY 3.0), which permits unrestricted use, distribution, and reproduction in any medium, provided the original author and source are credited.

\section{ABSTRACT}

Induction of necroptosis has emerged as an alternative approach to trigger programmed cell death, in particular in apoptosis-resistant cancer cells. Recent evidence suggests that kinase inhibitors targeting oncogenic B-RAF can also affect Receptor-interacting serine/threonine-protein kinase (RIP)1 and RIP3. Sorafenib, a multi-targeting kinase inhibitor with activity against B-RAF, is used for the treatment of acute leukemia. In the present study, we therefore investigated whether Sorafenib interferes with therapeutic induction of necroptosis in acute leukemia. Here, we report that Sorafenib inhibits necroptotic signaling and cell death in two models of necroptosis in acute leukemia. Sorafenib significantly reduces Second mitochondria-derived activator of caspases (Smac) mimetic-induced necroptosis in apoptosis-resistant acute myeloid leukemia (AML) cells as well as Smac mimetic/Tumor Necrosis Factor (TNF)a-induced necroptosis in FADD-deficient acute lymphoblastic leukemia (ALL) cells. Sub- to low micromolar concentrations of Sorafenib corresponding to its plasma levels reported in cancer patients are sufficient to inhibit necroptosis, emphasizing the clinical relevance of our findings. Furthermore, Sorafenib blocks Smac mimeticmediated phosphorylation of mixed-lineage kinase domain-like protein (MLKL) that marks its activation, indicating that Sorafenib targets components upstream of MLKL such as RIP1 and RIP3. Intriguingly, Sorafenib reduces the Smac mimetic/TNFastimulated interaction of RIP1 with RIP3 and MLKL, demonstrating that it interferes with the assembly of the necrosome complex. Importantly, Sorafenib significantly protects primary, patient-derived AML blasts from Smac mimetic-induced necroptosis. By demonstrating that Sorafenib limits the anti-leukemic activity of necroptosisinducing drugs in acute leukemia cells, our study has important implications for the use of Sorafenib in the treatment of acute leukemia.

\section{INTRODUCTION}

Necroptosis has recently been identified as a nonapoptotic form of programmed cell death and the serine/ threonine kinases RIP1 and RIP3 constitute key elements of the necroptosis signaling machinery [1]. A prototypic signaling pathway to necroptosis is engaged by the binding of TNF $\alpha$ to its cognate cell surface receptor TNF receptor 1 (TNFR1), which triggers formation of the socalled complex I at the TNFR1 [1]. This leads to K63linked polyubiquitination of RIP1 by cellular Inhibitor of Apoptosis (cIAP) proteins and activation of canonical 
Nuclear Factor kappaB (NF-кB). Upon internalization of TNFR1, secondary cell death complexes assemble in the cytosol. When caspase-8 activation is blocked, RIP1 is no longer cleaved and can interact with RIP3 to build up the necrosome resulting in activation of RIP1 and RIP3 in an autocrine/paracrine manner via reciprocal phosphorylation [2-4]. RIP3 subsequently phosphorylates and activates MLKL, a pseudokinase that lacks intrinsic kinase activity $[5,6]$. Upon its activation, MLKL forms oligomers and translocates from the cytosol to the plasma and intracellular membranes, where it disrupts membrane integrity [7, 8].

Necroptosis may offer an alternative option to trigger programmed cell death in cancer cells, as many cancers have evolved mechanisms to evade cell death [9]. In apoptosis-resistant cancers therapeutic induction of necroptosis may be of particular interest, as activated caspase- 8 has been shown to cleave and thus inactivate RIP1 [10]. This implies that apoptosis-resistant cancer cells are particularly susceptible to necroptosis.

Inhibitor of Apoptosis (IAP) proteins are a family of proteins that are involved in the regulation of programmed cell death [11]. For example, cIAP1 and cIAP2 restrain necroptosis by mediating the polyubiquitination of RIP1 via their E3 ligase activity. Small-molecule inhibitors of IAP proteins that resemble Smac, i.e. Smac mimetics, stimulate autoubiquitination and proteasomal degradation of cIAP proteins, thereby promoting the assembly of the necrosome leading to necroptosis under conditions when caspase activation is inhibited [9].

The kinase domain of human RIP1 and RIP3 shares high sequence similarity with the kinase domain of B-RAF [12]. In addition, structural comparison of inhibitor-bound RIP1 with the inhibitor-bound oncogenic kinase B-RAF revealed partially overlapping binding sites for the RIP1 inhibitor necrostatin-1 (Nec-1) and the B-RAF inhibitor Vemurafenib [12]. This suggests that kinase inhibitors that target oncogenic B-RAF might also affect RIP1 and/ or RIP3. Indeed, the B-RAF inhibitor Dabrafenib has recently been shown to inhibit RIP3 independently of its effect on the B-RAF family members [13]. Sorafenib is a multi-targeting tyrosine kinase inhibitor with activity against B-RAF, but also against other kinases such as FLT3, VEGF, PDGF receptor and c-KIT [14]. It is used for the treatment of various malignancies including AML and ALL $[15,16]$. In the present study, we therefore investigated the question as to whether or not Sorafenib interferes with necroptosis in apoptosis-resistant acute leukemia.

\section{RESULTS}

\section{Sorafenib protects AML cells from BV6-induced necroptosis}

We previously reported that Smac mimetics can engage necroptosis in AML cells expressing key components of necroptosis signaling when caspase activation and apoptosis are blocked [17]. To investigate whether Sorafenib modulates necroptosis in AML cells, we used the Smac mimetic BV6 in combination with the broad-range caspase inhibitor zVAD.fmk to trigger necroptotic cell death. Importantly, we found that the addition of Sorafenib at subtoxic concentrations significantly reduced BV6/zVAD.fmk-induced necroptosis in a dose-dependent manner in both Molm-13 and MV411 AML cells (Figure 1A).

To compare the anti-necroptotic activity of Sorafenib to an established RIP3 inhibitor, we used GSK'872, a small-molecule inhibitor described to block RIP3 [18]. GSK'872 significantly inhibited BV6/zVAD.fmk-induced cell death in AML cells (Figure 1B). Since the B-RAF inhibitor Dabrafenib has recently been reported to inhibit RIP3 by its adenosine- $5^{\prime}$-triphosphate (ATP)-competitive binding to the enzyme [19], we also tested the effect of Dabrafenib on the induction of necroptosis in AML cells. Of note, the addition of Dabrafenib significantly reduced BV6/zVAD.fmk-stimulated cell death in Molm-13 and MV4-11 AML cells (Figure 1C). Comparison of equimolar concentrations of Sorafenib, Dabrafenib and GSK'872 in AML cells showed that Sorafenib and GSK'872 exhibited a comparable potency to reduce necroptotic cell death, while Dabrafenib turned out to be the most effective inhibitor in this model of necroptosis (Figure 1D).

Since exposure of AML cells to Sorafenib has been reported to elicit cell death $[20,21]$, we monitored cell death upon treatment with Sorafenib over an extended period of time. Indeed, Sorafenib induced cell death in AML cells in a time-dependent manner with a relatively slow kinetic and no or little cell death after six to 24 hours (Figure 1E). Furthermore, we investigated the long-term effect of Sorafenib on BV6/zVAD.fmk-induced necroptosis. A multi-day assay showed that Sorafenib protected both AML cell lines from BV6/zVAD.fmkinduced necroptosis for up to 24 hours, while it lost its protective effects later on, in parallel with becoming cytotoxic as single agent (Figure 1E). This shows that the inhibitory effect of Sorafenib on necroptosis is not only dose- but also time-dependent.

\section{Sorafenib inhibits BV6-induced phosphorylation of MLKL in AML cells}

Since MLKL is considered as a crucial mediator of necroptosis [1], we next investigated whether Sorafenib interferes with the phosphorylation of MLKL, which marks its activation [1]. Importantly, addition of Sorafenib almost completely prevented BV6/zVAD.fmk-stimulated phosphorylation of MLKL in both Molm-13 and MV4-11 AML cells (Figure 2A). Similarly, MLKL phosphorylation in response to treatment with BV6/zVAD.fmk was suppressed in the presence of GSK'872 or Dabrafenib (Figure 2A). This confirms that Sorafenib blocks BV6/ 


\section{Molm13}

A

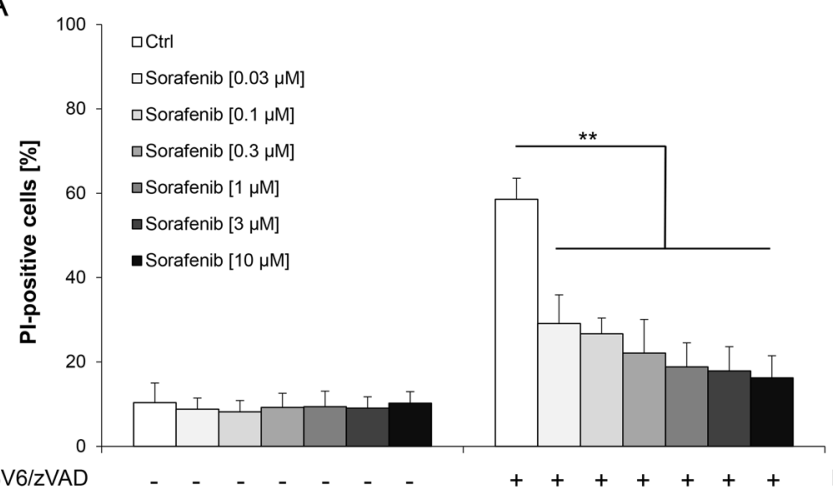

MV4-11

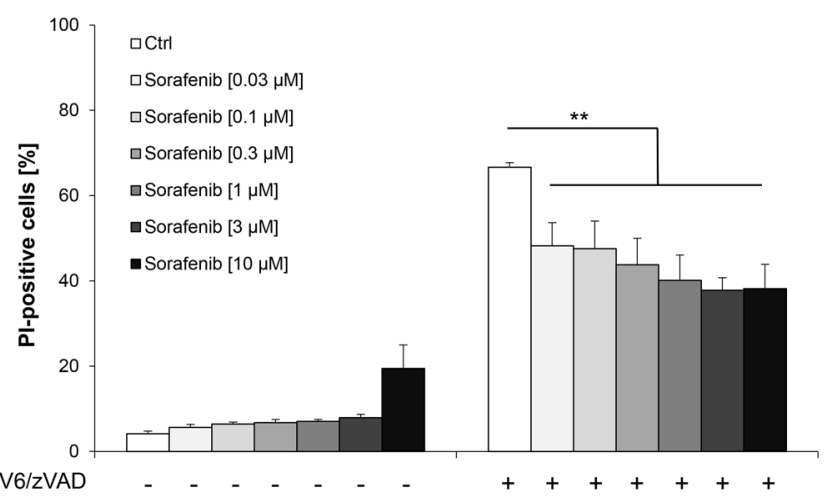

B

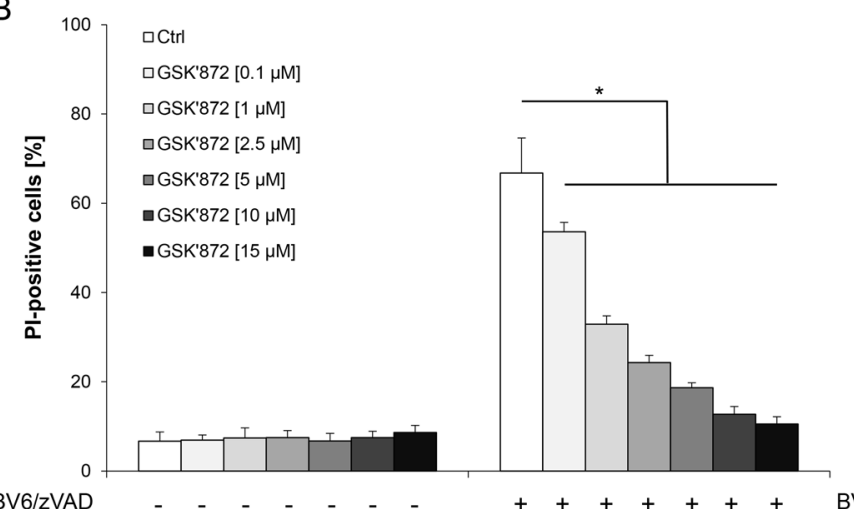

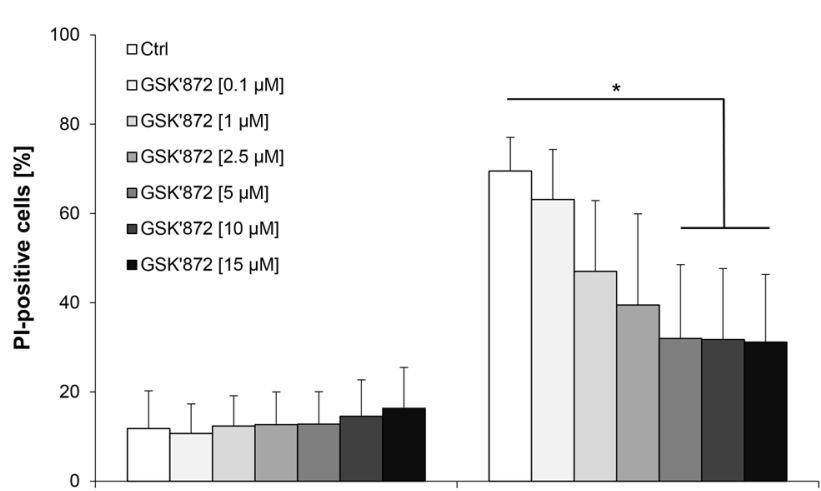

BV6/zVAD

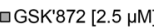

(1) $872[10 \mu \mathrm{M}]$

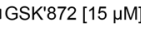

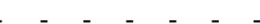

C

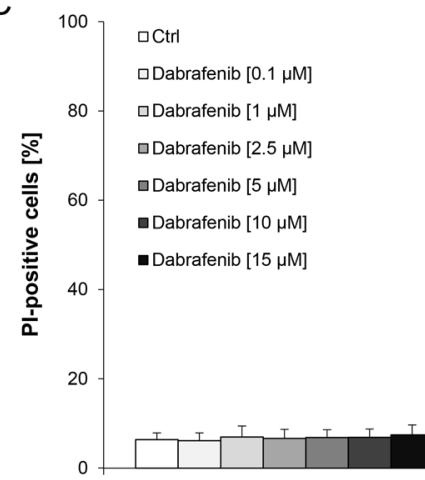

BV6/zVAD
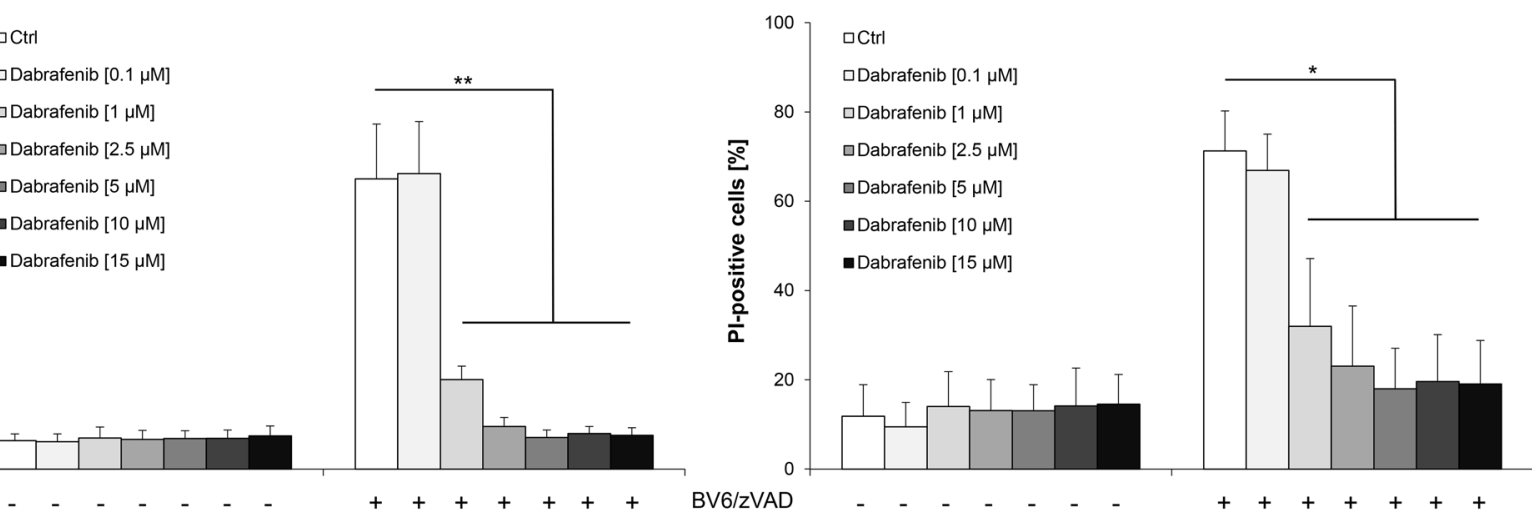

D
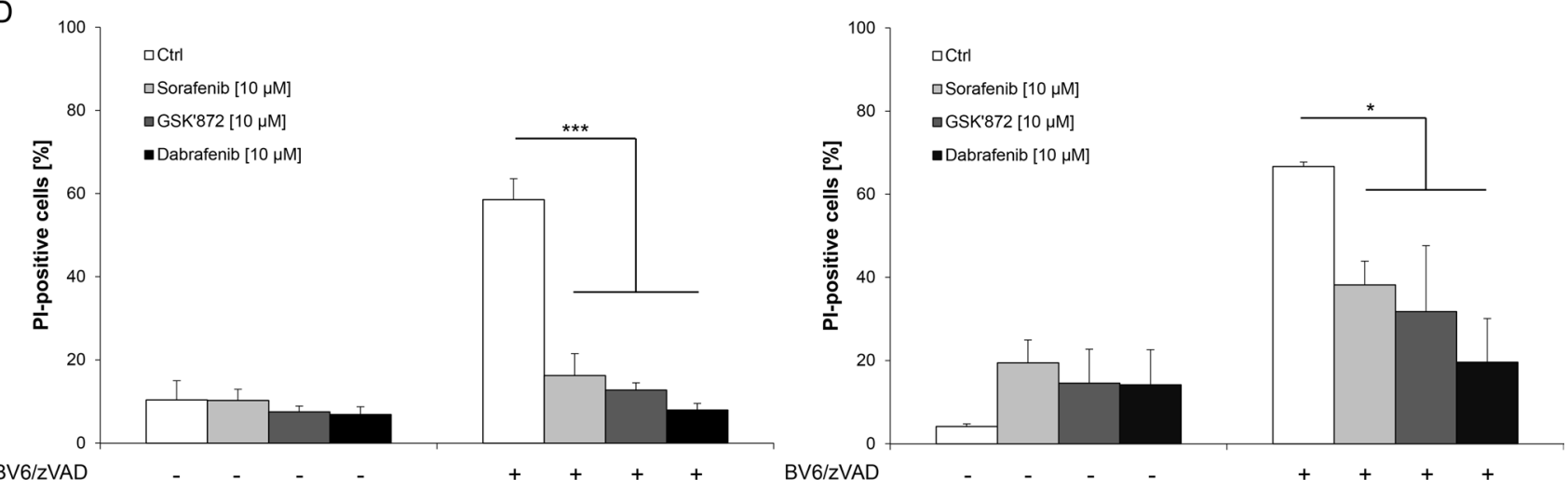

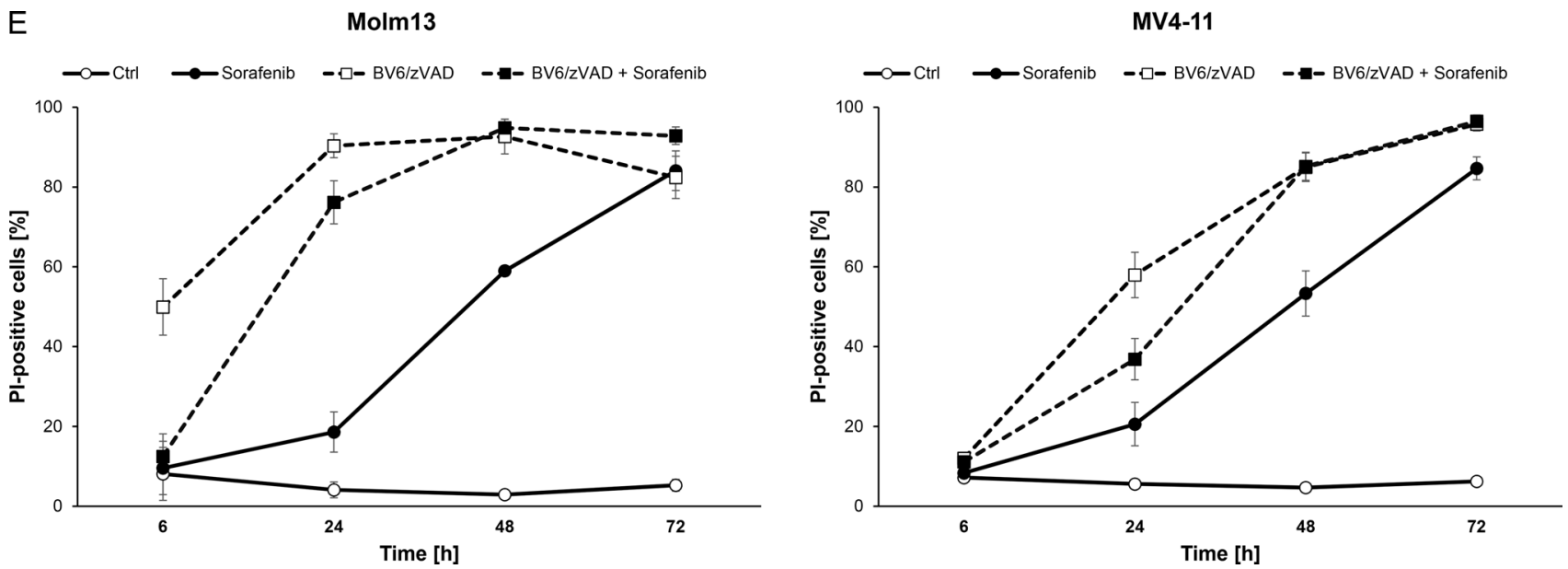

Figure 1: Sorafenib protects AML cells from BV6-induced necroptosis. (A-C) Molm13 and MV4-11 cells were treated for 6 hours (Molm13) or 24 hours (MV4-11) with $3 \mu \mathrm{M}$ BV6 and $40 \mu \mathrm{M}$ zVAD.fmk in the presence or absence of indicated concentrations of Sorafenib (A), GSK'872 (B) or Dabrafenib (C). (D) Molm13 and MV4-11 cells were treated for 6 hours (Molm13) or 24 hours (MV4-11) with $3 \mu \mathrm{M}$ BV6 and $40 \mu \mathrm{M}$ zVAD.fmk in the presence or absence of $10 \mu \mathrm{M}$ Sorafenib, $10 \mu \mathrm{M}$ GSK' 872 or $10 \mu \mathrm{M}$ Dabrafenib. (E) Molm13 and MV4-11 cells were treated with or without $3 \mu \mathrm{M}$ BV6 and $40 \mu \mathrm{M}$ zVAD.fmk in the presence or absence of $10 \mu \mathrm{M}$ Sorafenib for the indicated time points. (A-E) cell death was determined by PI staining and flow cytometry. Mean and SD of at least three experiments performed in triplicate are shown; $* P<0.05 ; * * P<0.01 ; * * * P<0.001$.

zVAD.fmk-mediated necroptosis in AML cells and indicates that Sorafenib targets components upstream of MLKL, such as RIP1 and RIP3.

Smac mimetics act by neutralizing IAP proteins and binding of Smac mimetics to cIAP proteins causes their ubiquitination and proteasomal degradation [22, 23]. To confirm that Sorafenib inhibits necroptotic signaling rather than interfering with BV6-induced depletion of cIAP proteins, we assessed the effects of Sorafenib on expression levels of cIAP1 in response to BV6 treatment. cIAP2 protein levels were not assessed, as cIAP2 is not detectable in Molm-13 and MV4-11 AML cells [24]. Neither Sorafenib nor GSK'872 or Dabrafenib prevented the BV6-stimulated downregulation of cIAP1 (Figure 2B).

\section{Sorafenib protects ALL cells from BV6/TNFa- induced necroptosis}

We then extended our experiments to a necroptosis model of ALL, since Sorafenib is also used for the treatment of ALL [16]. To this end, we used FADDdeficient Jurkat T-cell ALL cells, which undergo necroptosis upon treatment with BV6 in combination with $\mathrm{TNF} \alpha[25,26]$. Importantly, Sorafenib protected FADDdeficient Jurkat cells significantly at low micromolar concentrations from $\mathrm{BV} 6 / \mathrm{TNF} \alpha$-induced necroptosis in a dose-dependent manner (Figure 3A). Similarly, BV6/ $\mathrm{TNF} \alpha$-mediated cell death was significantly inhibited in the presence of GSK' 872 or Dabrafenib (Figure 3B, 3C). Comparison of equimolar concentrations of these inhibitors demonstrated that Sorafenib is slightly less potent than GSK' 872 to inhibit BV6/TNF $\alpha$-induced necroptotic cell death in FADD-deficient Jurkat cells and that Dabrafenib is superior to the latter two inhibitors in this setting (Figure 3D). Furthermore, phosphorylation of MLKL upon treatment with BV6/TNF $\alpha$ was almost completely blocked in the presence of Sorafenib, GSK'872 or Dabrafenib in FADD-deficient Jurkat cells (Figure 3E). Similar to the AML model, neither Sorafenib nor the RIP3 inhibitors GSK' 872 and Dabrafenib interfered with BV6imposed depletion of cIAP1 (Figure 3F).

As Sorafenib has been reported to induce cell death in ALL cells [27], we monitored the effect of Sorafenib over time. Similar to the AML model, the kinetic of Sorafenib-triggered cell death was relatively slow with no or little cell death after six to 24 hours (Figure 3G). At an early time point Sorafenib inhibited BV6/TNFainduced necroptosis in FADD-deficient Jurkat cells but not anymore after 24 hours of treatment, when it started to trigger cell death as single agent (Figure 3G). Together, this set of experiments shows that Sorafenib protects ALL cells from Smac mimetic/TNF $\alpha$-induced necroptosis in a time-dependent fashion.

\section{Sorafenib inhibits BV6/TNFa-induced assembly of the necrosome in acute leukemia cells}

As the necrosome complex represents a central signaling platform in necroptosis [1], we then asked whether Sorafenib alters the formation of the necrosome. To address this question, we treated FADD-deficient Jurkat cells with BV6/TNF $\alpha$ in the presence and absence of Sorafenib, immunoprecipitated RIP1 and analyzed its interaction with RIP3. Control experiments confirmed that we used equipotent concentrations of Sorafenib, 
GSK'872 and Dabrafenib for these immunoprecipitation studies that reduced $\mathrm{BV} 6 / \mathrm{TNF} \alpha$-induced cell death to a comparable extent by about $50 \%$ (data not shown). Intriguingly, the presence of Sorafenib reduced the BV6/TNF $\alpha$-stimulated interaction of RIP1 and RIP3 (Figure 4A). Similarly, Dabrafenib decreased binding of RIP3 to RIP1 in response to BV6/TNF $\alpha$ treatment (Figure 4A). We also observed that GSK'872 even promoted the interaction of RIP1 and RIP3 in BV6/ TNF $\alpha$-treated cells compared to cells that were stimulated with BV6/TNF $\alpha$ in the absence of GSK'872 (Figure 4A). A possible explanation for this finding is that GSK'872 alters the conformation of RIP3 thereby unleashing its RHIM-dependent oligomerization with RIP1 as recently reported [28].

To explore whether the ability of Dabrafenib to prevent necrosome assembly correlated with its ability to inhibit BV6/TNF $\alpha$-stimulated necroptosis, we also tested a higher concentration of Dabrafenib. Of note, Dabrafenib at a concentration of $5 \mu \mathrm{M}$, which entirely abrogated BV6/TNF $\alpha$-stimulated cell death (Figure 3C), almost completely abolished the interaction of RIP1 and RIP3 in

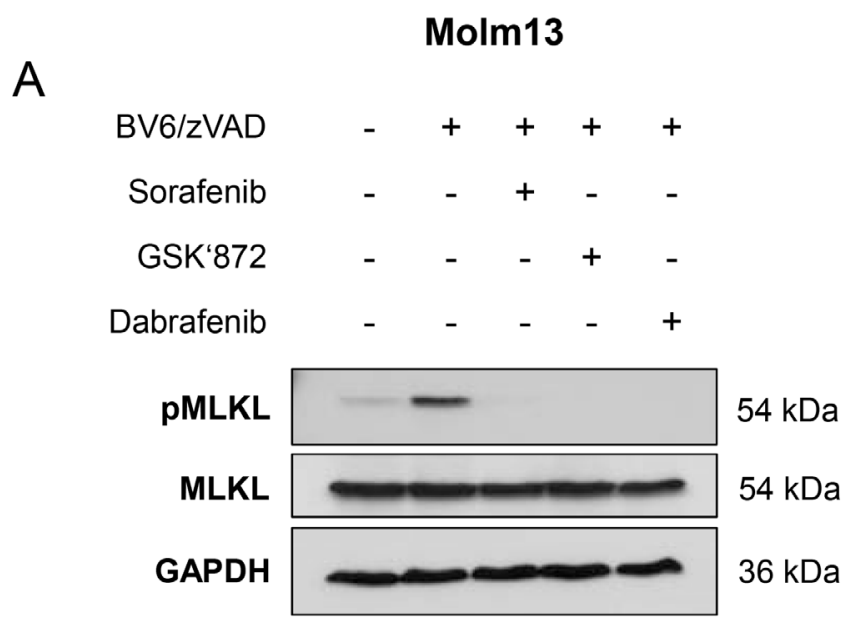

B

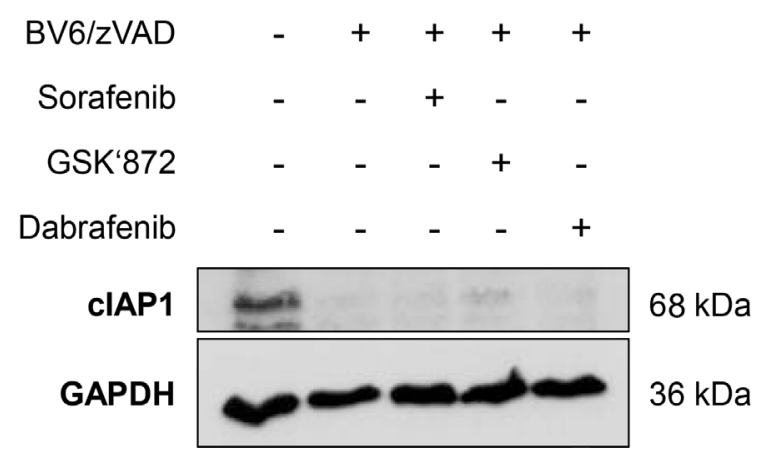

response to BV6/TNF $\alpha$ treatment (Figure 4B).

Furthermore, we investigated the question as to whether or not Sorafenib regulates the binding of MLKL to the necrosome complex. To this end, we immunoprecipitated RIP1 and analyzed its interaction with MLKL. Interestingly, the presence of Sorafenib reduced the BV6/TNF $\alpha$-stimulated interaction of RIP1 and MLKL (Figure 4C). Similarly, the interaction of RIP1 and MLKL upon BV6/TNF $\alpha$ treatment was attenuated in the presence of GSK'872 or Dabrafenib (Figure 4C). This set of experiments demonstrates that Sorafenib interferes with the assembly of the necrosome during BV6/TNF $\alpha$-induced necroptosis in leukemia cells.

\section{Sorafenib does not inhibit Smac mimetic- induced apoptosis in acute leukemia cells}

Next, we tested whether Sorafenib specifically inhibits BV6-induced necroptosis in acute leukemia cells. To this end, we investigated the effect of Sorafenib on BV6-induced apoptosis in RIP3-deficient and therefore necroptosis-resistant NB4 AML cells as well as in Jurkat
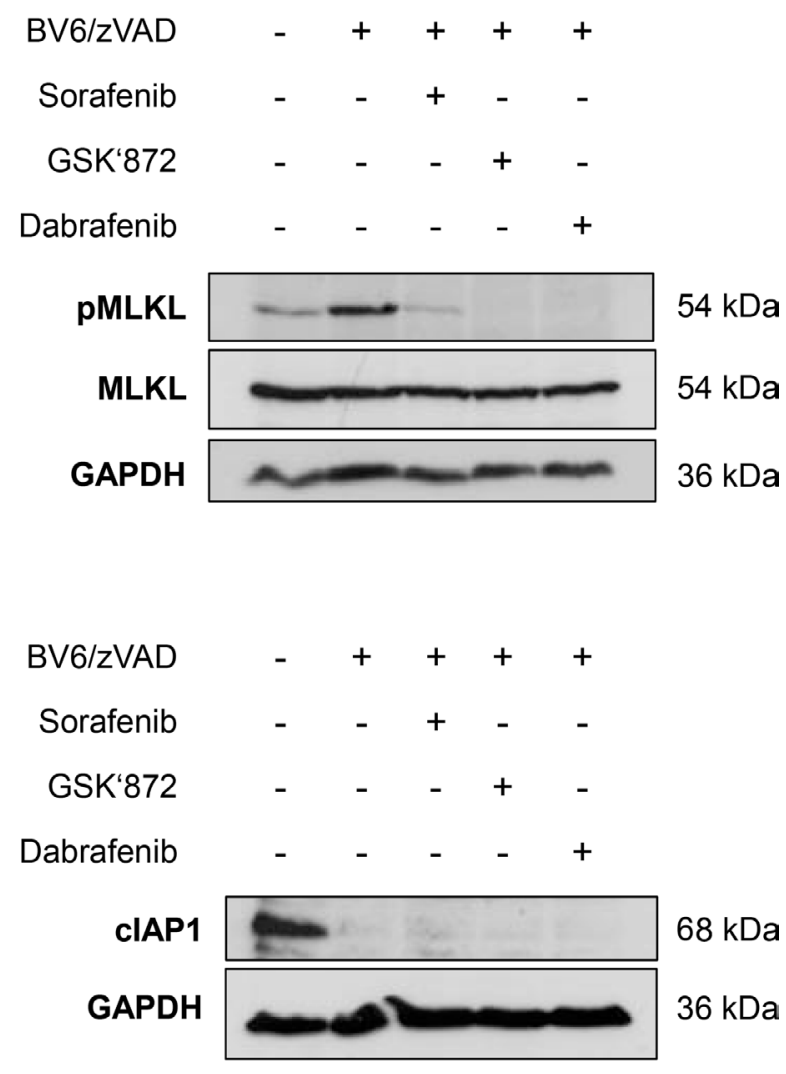

Figure 2: Sorafenib inhibits BV6-induced phosphorylation of MLKL in AML cells. (A) Molm13 and MV4-11 cells were treated for $4 \frac{1}{2}$ hours (Molm13) or 11 hours (MV4-11) with $3 \mu \mathrm{M}$ BV6 and $40 \mu \mathrm{M}$ zVAD.fmk in the presence or absence of $10 \mu \mathrm{M}$ Sorafenib, $15 \mu$ M GSK'872 or $5 \mu$ M Dabrafenib. (B) Molm13 and MV4-11 cells were treated for 5 $\frac{1}{2}$ hours (Molm13) or 7 hours (MV4-11) with $3 \mu \mathrm{M}$ BV6 and $40 \mu \mathrm{M}$ zVAD.fmk in the presence or absence of $10 \mu \mathrm{M}$ Sorafenib, $15 \mu \mathrm{M}$ GSK' 872 or $5 \mu \mathrm{M}$ Dabrafenib. Expression levels of MLKL and phospho-MLKL (A) or cIAP1 (B) were assessed by Western blotting, GAPDH served as loading control. 

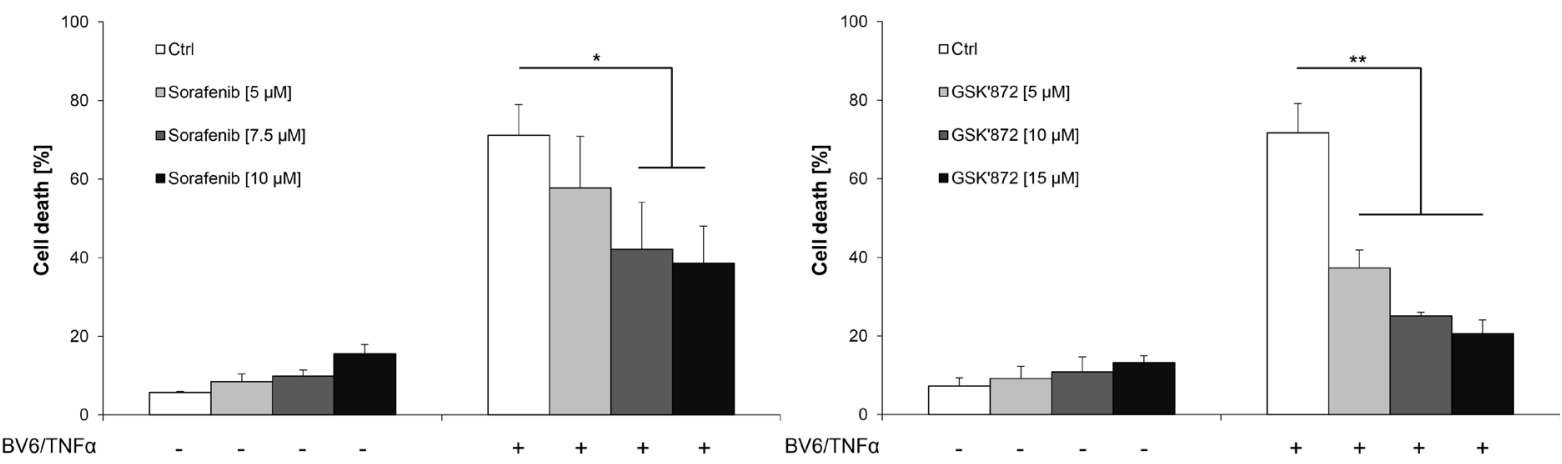

C

D
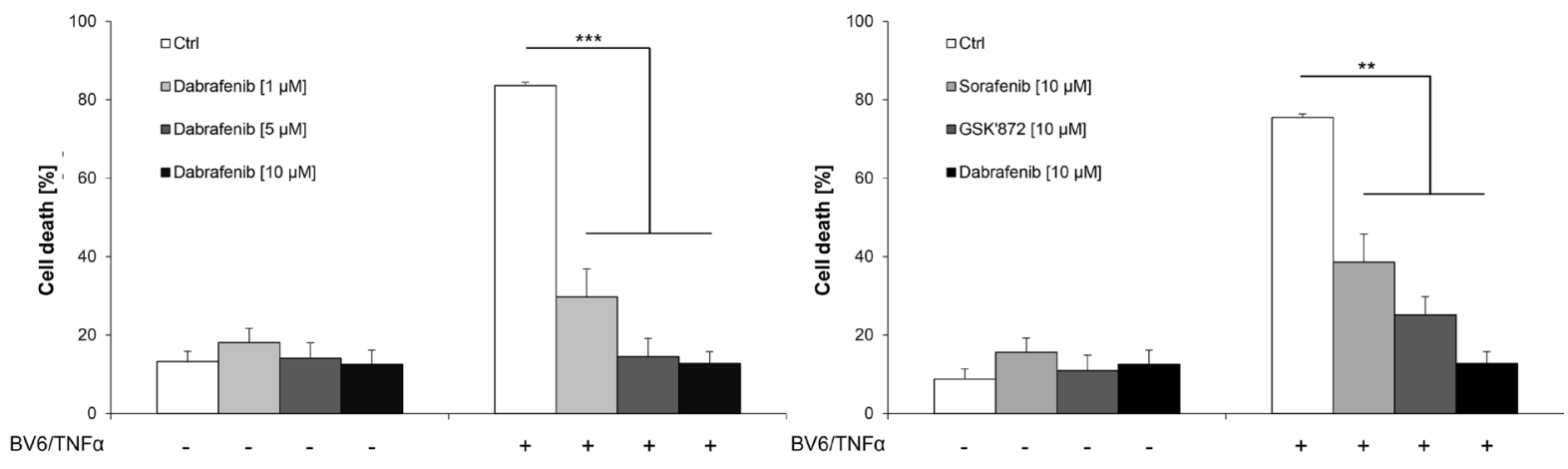

E

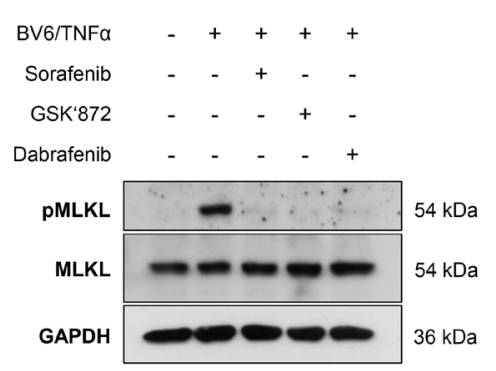

F

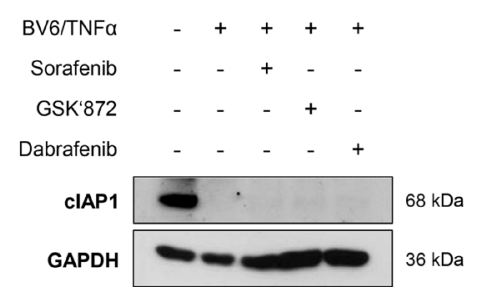

G

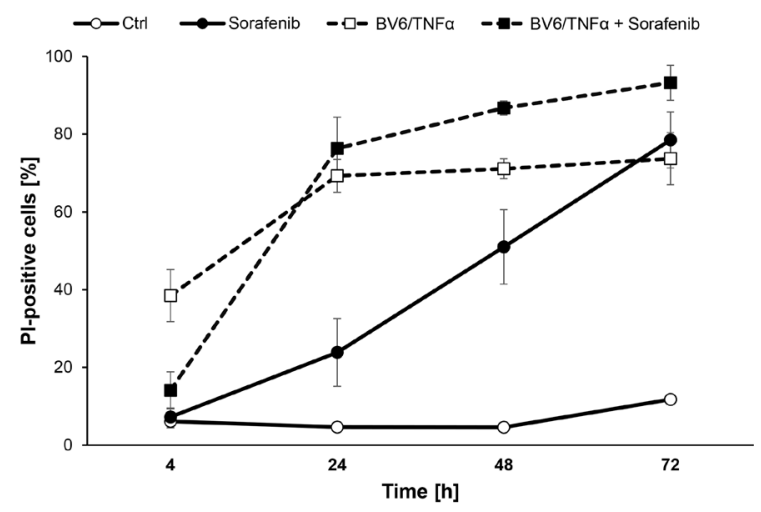

Figure 3: Sorafenib protects ALL cells from BV6/TNF $\alpha$-induced necroptosis. (A-C) FADD-deficient Jurkat cells were treated for 4 hours with $1 \mu \mathrm{M}$ BV6 and $1 \mathrm{ng} / \mathrm{ml} \mathrm{TNF} \alpha$ in the presence or absence of indicated concentrations of Sorafenib (A), GSK'872 (B) or Dabrafenib (C). (D) FADD-deficient Jurkat cells were treated for 4 hours with $1 \mu \mathrm{M}$ BV6 and $1 \mathrm{ng} / \mathrm{ml} \mathrm{TNF} \alpha$ in the presence or absence of $10 \mu \mathrm{M}$ Sorafenib, $10 \mu \mathrm{M}$ GSK'872 or $10 \mu \mathrm{M}$ Dabrafenib. (E and F) FADD-deficient Jurkat cells were treated for 2 hours with $1 \mu \mathrm{M}$ BV6 and $1 \mathrm{ng} / \mathrm{ml} \mathrm{TNF} \alpha$ in the presence or absence of $10 \mu \mathrm{M}$ Sorafenib, $6 \mu \mathrm{M}$ GSK'872 or 0.6 $\mu \mathrm{M}$ Dabrafenib. Expression levels of MLKL, phospho-MLKL and cIAP1 were analyzed by Western blotting, expression of GAPDH served as loading control. (G) FADD-deficient Jurkat cells were treated with or without $1 \mu \mathrm{M} \mathrm{BV} 6$ and $1 \mathrm{ng} / \mathrm{ml} \mathrm{TNF} \alpha$ in the presence or absence of $10 \mu \mathrm{M}$ Sorafenib for the indicated time points. Cell death was determined by FSC/SSC analysis (A-D) or PI staining (G) and flow cytometry. Mean and SD of at least three experiments performed in triplicate are shown; $* P<0.05 ; * * P<0.01 ; * * * P<0.001$. 
wild-type cells, which have previously been shown to undergo apoptosis upon $\mathrm{BV6} / \mathrm{TNF} \alpha$ treatment that is blocked by the caspase inhibitor zVAD.fmk [17, 26]. Of note, Sorafenib failed to rescue NB4 and Jurkat cells from BV6-induced apoptosis (Figure 5A, 5B).

These findings demonstrate that Sorafenib does not protect acute leukemia cells from Smac mimetic-induced apoptosis.

\section{Sorafenib rescues primary AML cells from BV6- induced necroptosis}

To investigate the clinical relevance of our results, we studied the effects of Sorafenib on necroptosis induction in primary leukemic blasts freshly isolated from a patient with AML at diagnosis. Importantly, non-toxic concentrations of Sorafenib substantially reduced BV6/ zVAD.fmk-induced cell death in primary AML cells (Figure 6). This demonstrates that Sorafenib impairs Smac mimetic-induced necroptosis not only in AML cell lines but also in primary, patient-derived AML blasts.

\section{DISCUSSION}

Sorafenib is a multi-targeting tyrosine kinase inhibitor that is used for the treatment of e.g. acute leukemia $[15,16]$. In the present study, we investigated whether Sorafenib interferes with therapeutic induction of necroptosis in acute leukemia.

Here, we report that Sorafenib inhibits necroptotic signaling and cell death in acute leukemia cells, when caspase activation and apoptosis are blocked by FADD deficiency or zVAD.fmk. This conclusion is supported by a number of arguments. First, Sorafenib inhibits necroptosis at sub- to low micromolar concentrations with a comparable potency to the small-molecule inhibitor GSK'872 that has been described to block RIP3 [18]. Second, Sorafenib interferes with the assembly of the necrosome complex upon the induction of necroptosis reducing the interaction of RIP1 with RIP3 and MLKL. Third, Sorafenib strongly attenuates phosphorylation of MLKL, a posttranslational modification that is mediated by RIP3 and marks its activation [5]. This indicates that Sorafenib targets components upstream of MLKL such as RIP1 and RIP3.

Sorafenib is a multi-targeting kinase inhibitor that inhibits B-RAF in addition to other kinases [14]. The fact that it inhibits RIP1 and RIP3 in addition to its known targets is supported by recent structural biology studies showing a strong structural homology between the kinase domains of both human RIP1 and RIP3 and the kinase domain of B-RAF [12]. This underscores that kinase inhibitors targeting oncogenic B-RAF might also affect RIP1 and RIP3. Indeed, there is recent evidence indicating that Sorafenib inhibits RIP1 and RIP3 kinase activity [29].
Sorafenib has also been reported to induce necroptosis based on data showing that the RIP1 inhibitor Nec-1 attenuated Sorafenib-mediated cell death in multiple myeloma, Hodgkin lymphoma or prostate carcinoma cells [30-32]. However, as RIP1 can control necroptotic as well as apoptotic pathways, Nec-1-conferred protection from cell death cannot be taken as sufficient evidence for necroptosis.

Besides Sorafenib, other kinase inhibitors that are currently being used as anticancer drugs have been reported to exhibit anti-necroptotic effects. The B-RAF inhibitor Dabrafenib has been shown to inhibit RIP3 through ATP-competitive binding to the enzyme, to inhibit necroptosis in cellular models and to alleviate toxic liver injury in vivo [13]. This Dabrafenib-imposed protection from necroptosis was described to occur independently of its effect on the B-RAF family members [13]. Consistently, we show in the present study that Dabrafenib protects acute leukemia cells from therapeutic induction of necroptosis. Furthermore, a cellular screen with Food and Drug Administration (FDA)-approved drugs identified the structurally distinct multi-targeting kinase inhibitors Pazopanib and Ponatinib as necroptosis inhibitors [33]. Ponatinib is a multikinase inhibitor, which targets BCRABL besides other kinases such as VEGF receptor, PDGF receptor, FGFR, FLT3 and c-KIT [34] and has been developed for the treatment of Philadelphia chromosomepositive acute leukemia [35]. Ponatinib has been shown to inhibit both RIP1 and RIP3 via direct binding $[33,36]$. The protective effect of Pazopanib, a receptor tyrosine kinase inhibitor targeting VEGF receptors, PDGF receptor and c-KIT [37], has been reported to be mediated via RIP1 as the main functional target [33]. Together, these reports show that several multi-kinase inhibitors with different activity spectra can protect from necroptosis by targeting RIP1 and/or RIP3.

The data on hand showing that Sorafenib can limit the anti-leukemic activity of necroptosis-inducing drugs in acute leukemia cells has important implications, as Sorafenib is currently being used in the clinic for the treatment of AML and ALL $[15,16]$. The induction of necroptosis has emerged in recent years as an alternative therapeutic approach to trigger programmed cell death in cancer cells, in particular in apoptosis-resistant cases [38]. In AML, we recently demonstrated that Smac mimetics alone or in combination with standard chemotherapeutic drugs such as cytarabine or epigenetic modifiers (i.e. demethylating agents, histone deacetylase (HDAC) inhibitors) can overcome apoptosis resistance of AML cells by inducing necroptosis as an alternative mode of programmed cell death [17, 24, 39, 40]. Also, Smac mimetics together with glucocorticoids, demethylating agents or TNF $\alpha$ have been shown to elicit necroptosis in apoptosis-resistant ALL cells [25, $41,42]$. Our current study demonstrating that Sorafenib 
A
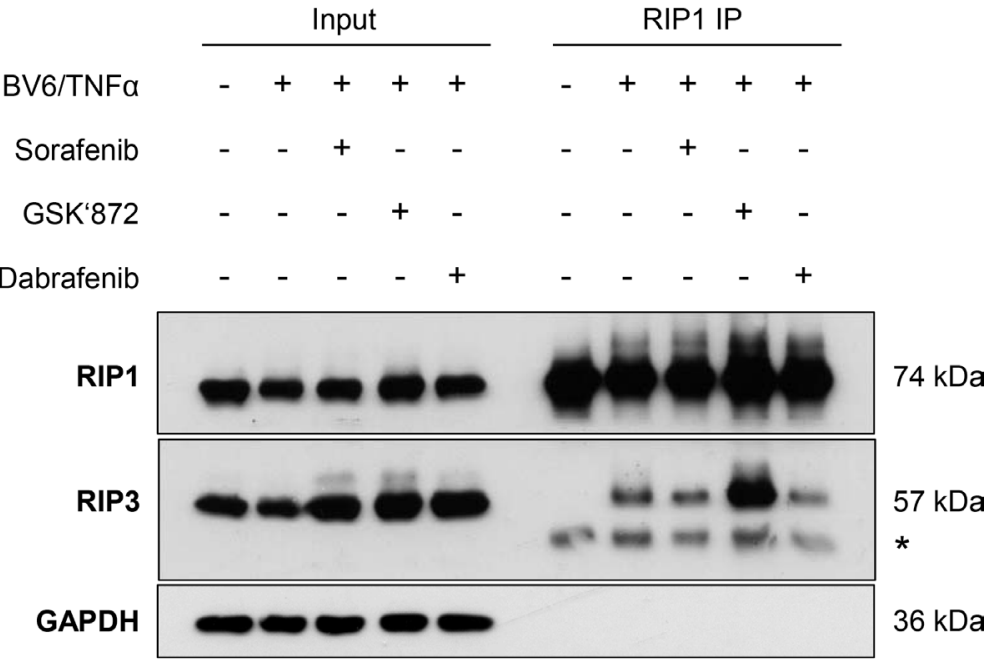

B

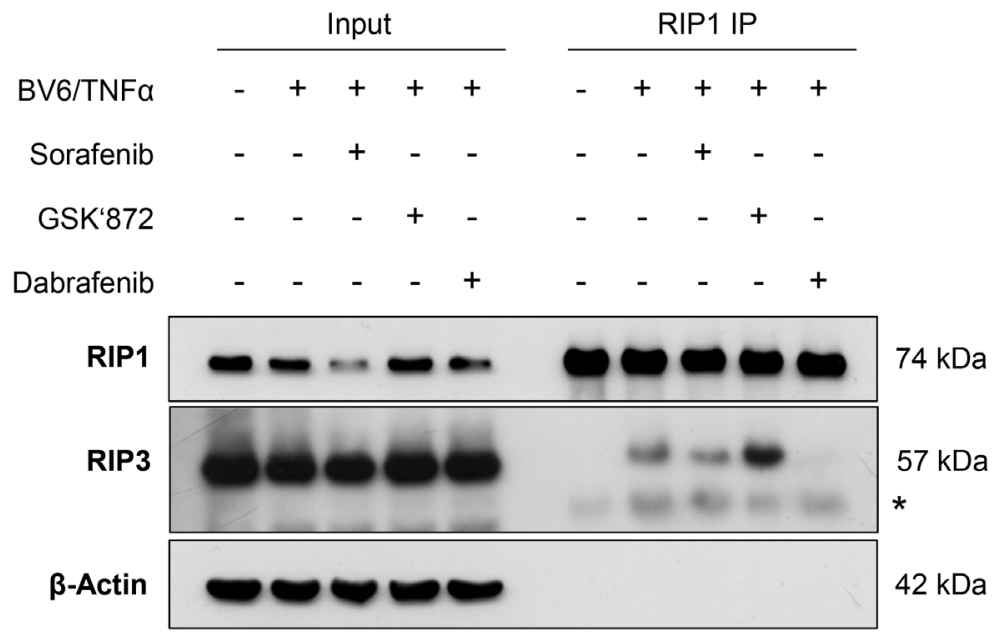

C

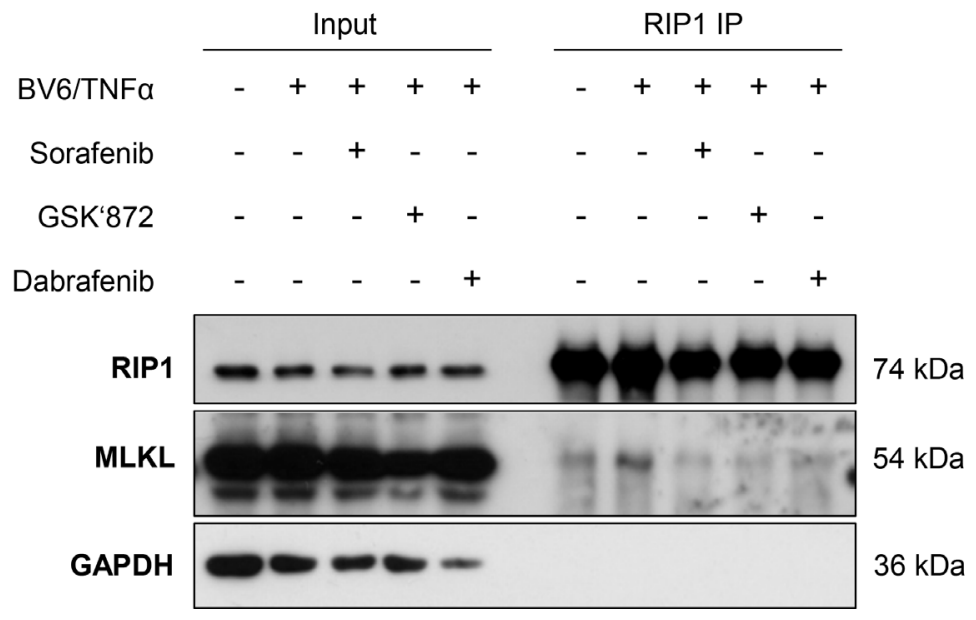

Figure 4: Sorafenib inhibits BV6/TNF $\alpha$-induced assembly of the necrosome in acute leukemia cells. (A) FADD-deficient Jurkat cells were treated for 2 hours with $1 \mu \mathrm{M} \mathrm{BV} 6$ and $1 \mathrm{ng} / \mathrm{ml} \mathrm{TNF} \alpha$ in the presence or absence of $10 \mu \mathrm{M}$ Sorafenib, $6 \mu \mathrm{M}$ GSK' 872 or $0.6 \mu \mathrm{M}$ Dabrafenib. RIP1 was immunoprecipitated using anti-RIP1 antibody and detection of indicated proteins was carried out by Western blotting; *: IgG heavy chain. (B) FADD-deficient Jurkat cells were treated for 2 hours with $1 \mu \mathrm{M} \mathrm{BV} 6$ and $1 \mathrm{ng} / \mathrm{ml}$ TNF $\alpha$ in the presence or absence of $10 \mu \mathrm{M}$ Sorafenib, $10 \mu \mathrm{M}$ GSK' 872 or $5 \mu \mathrm{M}$ Dabrafenib. RIP1 was immunoprecipitated using anti-RIP1 antibody and detection of indicated proteins was carried out by Western blotting; *: IgG heavy chain. (C) FADD-deficient Jurkat cells were treated for 2 hours with $1 \mu \mathrm{M} \mathrm{BV} 6$ and $1 \mathrm{ng} / \mathrm{ml} \mathrm{TNF} \alpha$ in the presence or absence of $10 \mu \mathrm{M}$ Sorafenib, $6 \mu \mathrm{M}$ GSK' 872 or $0.6 \mu \mathrm{M}$ Dabrafenib. RIP1 was immunoprecipitated using anti-RIP1 antibody crosslinked to beads and detection of indicated proteins was carried out by Western blotting. 
at sub- to low micromolar concentrations inhibits treatment-induced necroptosis in AML and ALL cells implies that Sorafenib may limit the anti-leukemic activity of anticancer drugs that trigger necroptosis under certain conditions, for example when caspase activation is blocked. Nevertheless, additional studies, e.g. using in vivo leukemia mouse models, are still outstanding to test whether Sorafenib may limit the antileukemic activity of necroptosis-inducing agents.
Also, downregulation of RIP3 has been reported in some human cancers including AML $[43,44]$. The clinical relevance of our findings is underscored by our data showing that Sorafenib impairs the therapeutic induction of necroptotic cell death by Smac mimetic not only in AML and ALL cell lines but also in primary, patientderived AML blasts. Furthermore, the concentrations of Sorafenib exhibiting anti-necroptotic effects in leukemia cells correspond to plasma levels of 3-17 $\mu \mathrm{M}$ Sorafenib
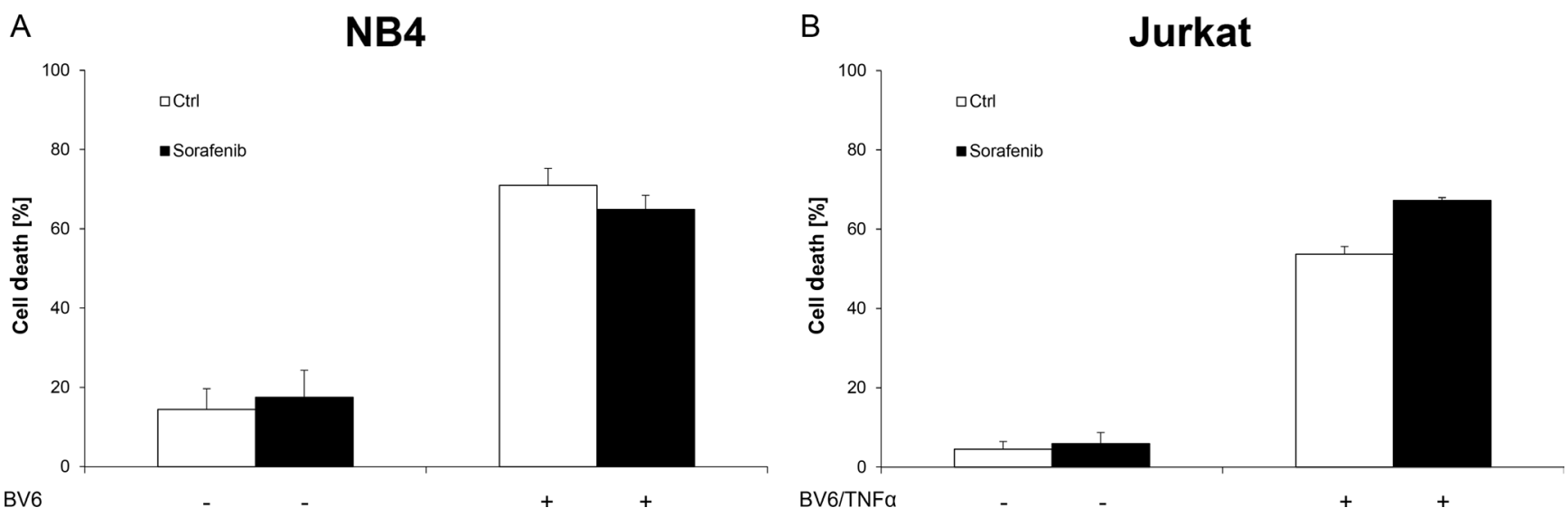

Figure 5: Sorafenib does not inhibit BV6-induced apoptosis in acute leukemia cells. (A) NB4 cells were treated for 7 hours with $7 \mu \mathrm{M}$ BV6 in the presence or absence of $10 \mu \mathrm{M}$ Sorafenib. (B) Jurkat cells were treated for 24 hours with $5 \mu \mathrm{M}$ BV6 and $1 \mathrm{ng} / \mathrm{ml}$ $\mathrm{TNF} \alpha$ in the presence or absence of $5 \mu \mathrm{M}$ Sorafenib. Cell death was determined by FSC/SSC analysis and flow cytometry. Mean and SD of at least three experiments performed in triplicate are shown; ${ }^{*} P<0.05 ; * * P<0.01 ; * * * P<0.001$.

\section{Primary AML cells}

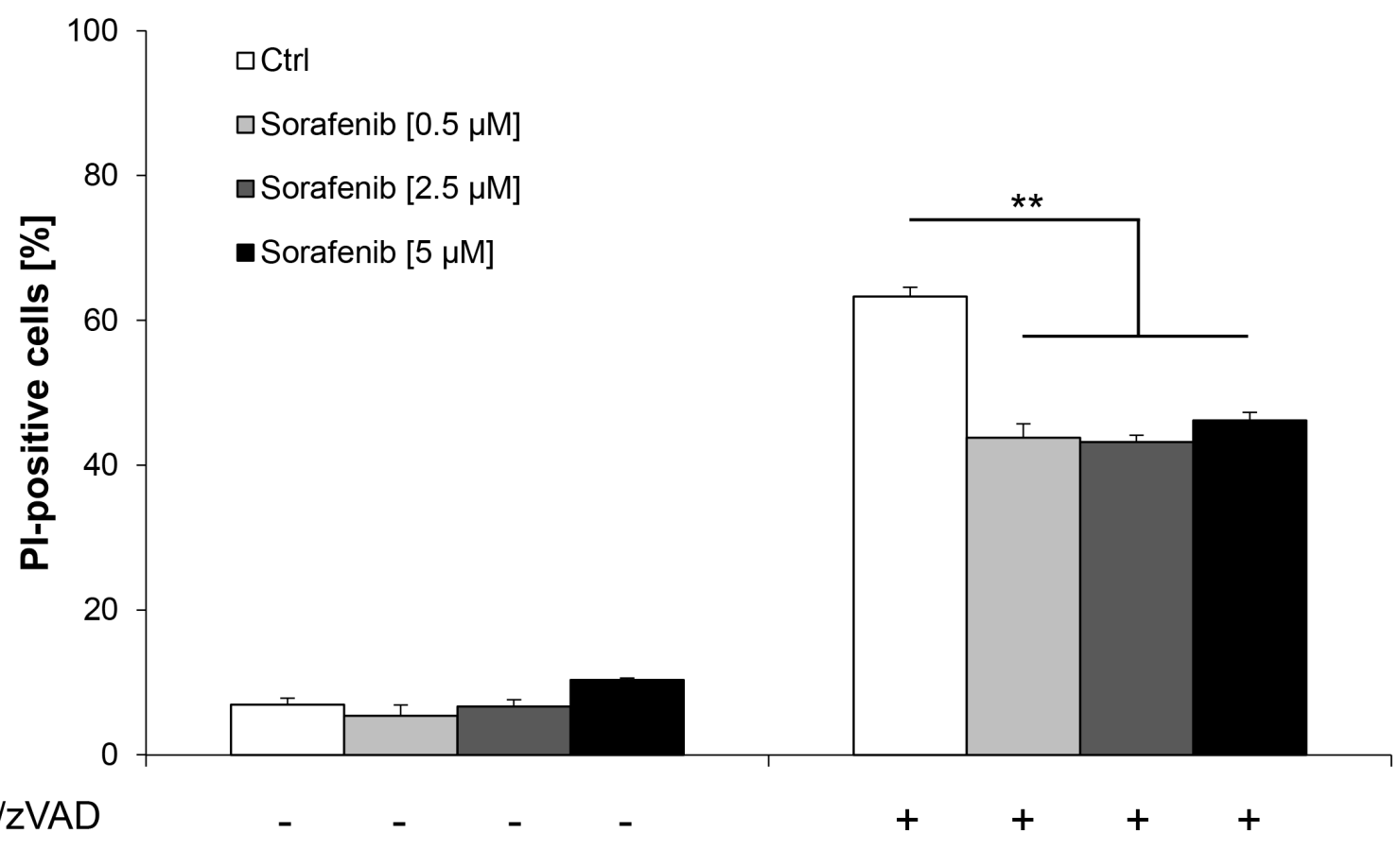

Figure 6: Sorafenib rescues primary AML cells from BV6-induced necroptosis. Primary AML cells were treated for 36 hours with $10 \mathrm{nM} \mathrm{BV} 6$ and $20 \mu \mathrm{M}$ zVAD.fmk in the presence or absence of indicated concentrations of Sorafenib. Cell death was determined by PI staining and flow cytometry. Mean and SD of triplicates are shown; $* P<0.05 ; * * P<0.01 ; * * * P<0.001$. 
that have been reported in cancer patients upon treatment with Sorafenib $[45,46]$. Taken together, our study has important implications for the use of Sorafenib in the treatment of acute leukemia.

\section{MATERIALS AND METHODS}

\section{Cell culture and chemicals}

AML cell lines were obtained from DSMZ (Braunschweig, Germany), FADD-deficient Jurkat cells were kindly provided by Dr. J. Blenis [47]. Cells were cultured in RPMI 1640 medium (Life Technologies, Inc., Eggenstein, Germany), supplemented with $10 \%$ or $20 \%$ fetal calf serum (FCS) (Biochrom, Berlin, Germany), 1\% penicillin/streptomycin (Invitrogen, Karlsruhe, Germany) and $1 \mathrm{mM}$ sodium pyruvate (Invitrogen) for AML cell lines or $2.5 \%$ HEPES (Invitrogen) for ALL cell lines. Primary AML cells were maintained in Iscove's Modified Dulbecco's Medium with GlutaMAX ${ }^{\mathrm{TM}}$ supplement (Life Technologies) supplemented with 10\% FCS, 1\% penicillin/streptomycin, $1 \%$ sodium pyruvate, $1 \%$ nonessential amino acid, $8 \mathrm{ng} / \mathrm{ml}$ interleukin-3, $20 \mathrm{ng} / \mathrm{ml}$ granulocyte-macrophage colony-stimulating factor, $20 \mathrm{ng} / \mathrm{ml}$ stem cell factor and $50 \mu \mathrm{M} 2$ 2-mercaptoethanol. Biomaterial and clinical data were obtained from the hematological biobank and the tumor documentation of the UCT Frankfurt (Germany), characteristics of the sample are summarized in Supplementary Table 1. The study protocol has been approved by the local ethics committee of the University Hospital Frankfurt and informed consent has been obtained. The Smac mimetic BV6, which neutralizes x-linked IAP (XIAP), cIAP1 and cIAP2 [22], was kindly provided by Genentech, Inc. (South San Francisco, CA, USA). Caspase inhibitor zVAD. fmk was obtained from Bachem (Heidelberg, Germany), TNF $\alpha$ from Biomol (Hamburg, Germany), GSK'872 from Merck (Darmstadt, Germany), Sorafenib from Bayer AG (Leverkusen, Germany), Dabrafenib from Selleckchem (Houston, TX, USA). All chemicals were purchased by Sigma-Aldrich (Taufkirchen, Germany) or Carl Roth (Karlsruhe, Germany) unless indicated otherwise. Cells were preincubated with inhibitors (zVAD.fmk, Sorafenib, GSK'872 or Dabrafenib) for one hour before treatment. BV6 was applied two hours before stimulation with TNF $\alpha$.

\section{Western blot analysis}

Western blot analysis was performed as described previously [48] using the following antibodies: cIAP1 (R\&D Systems, Inc., Wiesbaden, Germany), RIP1 (BD Biosciences, Heidelberg, Germany), RIP3 (Novus Biologicals, Littleton, CO, USA), MLKL (GeneTex, Irvine, CA, USA), phospho-MLKL (Cell Signaling Technologies, Danvers, MA, USA), $\beta$-Actin (SigmaAldrich) and glyceraldehyde 3-phosphate dehydrogenase
(GAPDH) (HyTest, Turku, Finland) as loading controls and secondary antibodies conjugated to horseradish peroxidase (Santa Cruz Biotechnology, Santa Cruz, CA, USA). Enhanced chemiluminescence was used for detection (Amersham Bioscience, Freiburg, Germany). Alternatively, secondary antibodies labeled with IRDye infrared dyes were used for fluorescence detection (Odyssey Imaging System, LI-COR Bioscience, Bad Homburg, Germany). All Western blots shown are representative of at least two independent experiments.

\section{Determination of cell death}

Cell death was assessed by forward/side scatter (FSC/SSC) analysis and flow cytometry as described previously [49] or by determination of plasma membrane permeability using propidium iodide (PI) staining (SigmaAldrich) and flow cytometry.

\section{Immunoprecipitation}

RIP1 immunoprecipitation was performed as previously described [25]. Briefly, cells were lysed in nonidet P-40 (NP-40) buffer (10 mM Tris ( $\mathrm{pH} 8.0$ ), $150 \mathrm{mM} \mathrm{NaCl}, 1 \% \mathrm{NP}-40$ ), supplemented with protease inhibitor cocktail (Roche, Grenzach, Germany) and phosphatase inhibitors (1 $\mathrm{mM}$ sodium orthovanadate, $1 \mathrm{mM} \beta$-glycerophosphate, $5 \mathrm{mM}$ sodium fluoride). At least $1.5 \mathrm{mg}$ of protein was incubated with $1.5 \mu \mathrm{g}$ of mouse anti-RIP1 antibody (no. 610459; BD Biosciences) overnight at $4^{\circ} \mathrm{C}$ followed by the addition of $15 \mu$ panmouse IgG Dynabeads (Invitrogen), and then rotated for at least two hours at $4^{\circ} \mathrm{C}$ and washed with NP-40 buffer. Denaturated samples were analyzed by Western blot for the expression of RIP1, RIP3 and MLKL. For analyzing the interaction of RIP1 and MLKL, the RIP1 antibody was crosslinked to beads using dimethyl pimelimidate ((DMP); Thermo Scientific, Rockford, USA).

\section{Statistical analysis}

Statistical significance was assessed by Student's $t$-test (two-tailed distribution, two-sample, unequal variance).

\section{Abbreviations}

ALL, acute lymphoblastic leukemia; AML, acute myeloid leukemia; ATP, adenosine-5'-triphosphate; cIAP, cellular Inhibitor of Apoptosis; DMP, dimethyl pimelimidate; FADD, Fas-Associated protein with Death Domain; FCS, fetal calf serum; FDA, Food and Drug Administration; FSC/SSC, forward/side scatter; GAPDH, glyceraldehyde 3-phosphate dehydrogenase; HDAC, histone deacetylase; IAP, Inhibitor of Apoptosis; MLKL, mixed-lineage kinase domain-like protein; Nec- 
1, necrostatin-1; NF-кB, Nuclear Factor kappaB; PI, propidium iodide; RIPK, receptor-interacting serine/ threonine-protein kinase; Smac, Second mitochondriaderived activator of caspases; TNF, Tumor Necrosis Factor; TNFR, TNF receptor; XIAP, x-linked IAP.

\section{Author contributions}

F.F. performed experiments, analyzed and interpreted data and prepared the manuscript together with S.F.; B.S., S.M. and P.V. contributed to design and interpretation of data; S.F. designed research, analyzed and interpreted data, supervised the project and prepared together with F.F. the manuscript; all authors approved the final version of the paper.

\section{ACKNOWLEDGMENTS}

We thank D. Vucic for kindly providing BV6 and C. Hugenberg for expert secretarial assistance.

\section{CONFLICTS OF INTEREST}

None to declare.

\section{FUNDING}

This work has been partially supported by grants from the BMBF, the DFG (SFB815) and the WilhelmSander Stiftung (to S.F.) and a grant from the Belgian science policy office (BELSPO) (IAP 7/32) and (to S.F. and P.V.). Peter Vandenabeele is recipient of a Methusalem grant (BOF09/01M00709 and BOF16/MET_V/007). Research in the Vandenabeele group is supported by grants from the Vlaams Instituut voor Biotechnologie (VIB), from Ghent University (MRP, GROUP-ID consortium), grants from the 'Foundation against Cancer' (2012188 and FAF-F/2016/865), grants from the Fonds voor Wetenschappelijk Onderzoek Vlaanderen (FWO) (FWO G.0875.11, FWO G.0A45.12N, FWO G.0787.13N, FWO G.0C37.14N, FWO G.0E04.16N).

\section{REFERENCES}

1. Vanden Berghe $T$, Linkermann A, Jouan-Lanhouet $\mathrm{S}$, Walczak H, Vandenabeele P. Regulated necrosis: the expanding network of non-apoptotic cell death pathways. Nat Rev Mol Cell Biol. 2014; 15:135-147.

2. Cho YS, Challa S, Moquin D, Genga R, Ray TD, Guildford M, Chan FK. Phosphorylation-driven assembly of the RIP1RIP3 complex regulates programmed necrosis and virusinduced inflammation. Cell. 2009; 137:1112-1123.

3. He S, Wang L, Miao L, Wang T, Du F, Zhao L, Wang X. Receptor interacting protein kinase-3 determines cellular necrotic response to TNF-alpha. Cell. 2009; 137:1100-1111.

4. Zhang DW, Shao J, Lin J, Zhang N, Lu BJ, Lin SC, Dong MQ, Han J. RIP3, an energy metabolism regulator that switches TNF-induced cell death from apoptosis to necrosis. Science. 2009; 325:332-336.

5. Sun L, Wang H, Wang Z, He S, Chen S, Liao D, Wang L, Yan J, Liu W, Lei X, Wang X. Mixed lineage kinase domainlike protein mediates necrosis signaling downstream of RIP3 kinase. Cell. 2012; 148:213-227.

6. Zhao J, Jitkaew S, Cai Z, Choksi S, Li Q, Luo J, Liu ZG. Mixed lineage kinase domain-like is a key receptor interacting protein 3 downstream component of TNFinduced necrosis. Proc Natl Acad Sci USA. 2012; 109:5322-5327.

7. Wang H, Sun L, Su L, Rizo J, Liu L, Wang LF, Wang FS, Wang X. Mixed lineage kinase domain-like protein MLKL causes necrotic membrane disruption upon phosphorylation by RIP3. Mol Cell. 2014; 54:133-146.

8. Dondelinger Y, Declercq W, Montessuit S, Roelandt R, Goncalves A, Bruggeman I, Hulpiau P, Weber K, Sehon CA, Marquis RW, Bertin J, Gough PJ, Savvides S, et al. MLKL Compromises Plasma Membrane Integrity by Binding to Phosphatidylinositol Phosphates. Cell Reports. 2014; 7:971-981.

9. Fulda S. Therapeutic exploitation of necroptosis for cancer therapy. Semin Cell Dev Biol. 2014; 35:51-56.

10. Oberst A, Dillon CP, Weinlich R, McCormick LL, Fitzgerald P, Pop C, Hakem R, Salvesen GS, Green DR. Catalytic activity of the caspase-8-FLIP(L) complex inhibits RIPK3-dependent necrosis. Nature. 2011; 471:363-367.

11. Fulda S, Vucic D. Targeting IAP proteins for therapeutic intervention in cancer. Nat Rev Drug Discov. 2012; 11:109-124.

12. Xie T, Peng W, Liu Y, Yan C, Maki J, Degterev A, Yuan J, Shi Y. Structural basis of RIP1 inhibition by necrostatins. Structure. 2013; 21:493-499.

13. Li JX, Feng JM, Wang Y, Li XH, Chen XX, Su Y, Shen YY, Chen Y, Xiong B, Yang CH, Ding J, Miao ZH. The B-Raf(V600E) inhibitor dabrafenib selectively inhibits RIP3 and alleviates acetaminophen-induced liver injury. Cell Death Dis. 2014; 5:e1278.

14. Wilhelm S, Carter C, Lynch M, Lowinger T, Dumas J, Smith RA, Schwartz B, Simantov R, Kelley S. Discovery and development of sorafenib: a multikinase inhibitor for treating cancer. Nat Rev Drug Discov. 2006; 5:835-844.

15. Daver N, Konopleva M. Sorafenib and novel multikinase inhibitors in AML. Lancet Oncol. 2015; 16:1582-1583.

16. Lee L, Fielding AK. Emerging pharmacotherapies for adult patients with acute lymphoblastic leukemia. Clin Med Insights Oncol. 2012; 6:85-100.

17. Safferthal C, Rohde K, Fulda S. Therapeutic targeting of necroptosis by Smac mimetic bypasses apoptosis resistance in acute myeloid leukemia cells. Oncogene. 2017; 36:1487-1502. 
18. Kaiser WJ, Sridharan H, Huang C, Mandal P, Upton JW, Gough PJ, Sehon CA, Marquis RW, Bertin J, Mocarski ES. Toll-like receptor 3-mediated necrosis via TRIF, RIP3, and MLKL. J Biol Chem. 2013; 288:31268-31279.

19. Xie F, Sun S, Xu A, Zheng S, Xue M, Wu P, Zeng JH, Bai L. Advanced oxidation protein products induce intestine epithelial cell death through a redox-dependent, c-jun N-terminal kinase and poly (ADP-ribose) polymerase-1mediated pathway. Cell Death Dis. 2014; 5:e1006.

20. Zhang W, Konopleva M, Shi YX, McQueen T, Harris D, Ling X, Estrov Z, Quintas-Cardama A, Small D, Cortes J, Andreeff M. Mutant FLT3: a direct target of sorafenib in acute myelogenous leukemia. J Natl Cancer Inst. 2008; 100:184-198.

21. Zhang W, Konopleva M, Ruvolo VR, McQueen T, Evans RL, Bornmann WG, McCubrey J, Cortes J, Andreeff M. Sorafenib induces apoptosis of AML cells via Bim-mediated activation of the intrinsic apoptotic pathway. Leukemia. 2008; 22:808-818.

22. Varfolomeev E, Blankenship JW, Wayson SM, Fedorova AV, Kayagaki N, Garg P, Zobel K, Dynek JN, Elliott LO, Wallweber HJ, Flygare JA, Fairbrother WJ, Deshayes K, et al. IAP antagonists induce autoubiquitination of c-IAPs, NF-kappaB activation, and TNFalpha-dependent apoptosis. Cell. 2007; 131:669-681.

23. Vince JE, Wong WW, Khan N, Feltham R, Chau D, Ahmed AU, Benetatos CA, Chunduru SK, Condon SM, McKinlay M, Brink R, Leverkus M, Tergaonkar V, et al. IAP antagonists target cIAP1 to induce TNFalphadependent apoptosis. Cell. 2007; 131:682-693.

24. Chromik J, Safferthal C, Serve H, Fulda S. Smac mimetic primes apoptosis-resistant acute myeloid leukaemia cells for cytarabine-induced cell death by triggering necroptosis. Cancer Lett. 2014; 344:101-109.

25. Schenk B, Fulda S. Reactive oxygen species regulate Smac mimetic/TNFalpha-induced necroptotic signaling and cell death. Oncogene. 2015; 34:5796-5806.

26. Laukens B, Jennewein C, Schenk B, Vanlangenakker N, Schier A, Cristofanon S, Zobel K, Deshayes K, Vucic D, Jeremias I, Bertrand MJ, Vandenabeele P, Fulda S. Smac Mimetic Bypasses Apoptosis Resistance in FADD- or Caspase8-Deficient Cells by Priming for Tumor Necrosis Factor alphaInduced Necroptosis. Neoplasia. 2011; 13:971-979.

27. Schult C, Dahlhaus M, Ruck S, Sawitzky M, Amoroso F, Lange S, Etro D, Glass A, Fuellen G, Boldt S, Wolkenhauer O, Neri LM, Freund M, et al. The multikinase inhibitor Sorafenib displays significant antiproliferative effects and induces apoptosis via caspase 3, 7 and PARP in B- and T-lymphoblastic cells. BMC Cancer. 2010; 10:560.

28. Mandal P, Berger SB, Pillay S, Moriwaki K, Huang C, Guo H, Lich JD, Finger J, Kasparcova V, Votta B, Ouellette M, King BW, Wisnoski D, et al. RIP3 induces apoptosis independent of pronecrotic kinase activity. Mol Cell. 2014; 56:481-495.
29. Martens S, Jeong M, Tonnus W, Feldmann F, Hofmans S, Goossens V, Takahashi N, Bräsen JH, Lee EW, Van der Veken P, Joossens J, Augustyns K, Fulda S, et al. Sorafenib tosylate inhibits directly necrosome complex formation and protects in mouse models of inflammation and tissue injury. Cell Death Dis. 2017; 8:e2904.

30. Ramirez-Labrada A, Lopez-Royuela N, Jarauta V, GalanMalo P, Azaceta G, Palomera L, Pardo J, Anel A, Marzo I, Naval J. Two death pathways induced by sorafenib in myeloma cells: Puma-mediated apoptosis and necroptosis. Clin Transl Oncol. 2015; 17:121-132.

31. Locatelli SL, Cleris L, Stirparo GG, Tartari S, Saba E, Pierdominici M, Malorni W, Carbone A, Anichini A, CarloStella C. BIM upregulation and ROS-dependent necroptosis mediate the antitumor effects of the HDACi Givinostat and Sorafenib in Hodgkin lymphoma cell line xenografts. Leukemia. 2014; 28:1861-1871.

32. Kharaziha $P$, Chioureas D, Baltatzis G, Fonseca $P$, Rodriguez P, Gogvadze V, Lennartsson L, Bjorklund AC, Zhivotovsky B, Grander D, Egevad L, Nilsson S, Panaretakis T. Sorafenib-induced defective autophagy promotes cell death by necroptosis. Oncotarget. 2015; 6:37066-82. https://doi.org/10.18632/oncotarget.5797.

33. Fauster A, Rebsamen M, Huber KV, Bigenzahn JW, Stukalov A, Lardeau CH, Scorzoni S, Bruckner M, Gridling M, Parapatics K, Colinge J, Bennett KL, Kubicek S, et al. A cellular screen identifies ponatinib and pazopanib as inhibitors of necroptosis. Cell Death Dis. 2015; 6:e1767.

34. Miller GD, Bruno BJ, Lim CS. Resistant mutations in CML and $\mathrm{Ph}(+) \mathrm{ALL}$ - role of ponatinib. Biologics. 2014; 8:243-254.

35. O'Hare T, Shakespeare WC, Zhu X, Eide CA, Rivera VM, Wang F, Adrian LT, Zhou T, Huang WS, Xu Q, Metcalf CA 3rd, Tyner JW, Loriaux MM, et al. AP24534, a panBCR-ABL inhibitor for chronic myeloid leukemia, potently inhibits the T315I mutant and overcomes mutation-based resistance. Cancer Cell. 2009; 16:401-412.

36. Najjar M, Suebsuwong C, Ray SS, Thapa RJ, Maki JL, Nogusa S, Shah S, Saleh D, Gough PJ, Bertin J, Yuan J, Balachandran S, Cuny GD, Degterev A. Structure guided design of potent and selective ponatinib-based hybrid inhibitors for RIPK1. Cell Reports. 2015; 10:1850-60.

37. Harris PA, Boloor A, Cheung M, Kumar R, Crosby RM, Davis-Ward RG, Epperly AH, Hinkle KW, Hunter RN 3rd, Johnson JH, Knick VB, Laudeman CP, Luttrell DK, et al. Discovery of 5-[[4-[(2,3-dimethyl-2H-indazol6-yl)methylamino]-2-pyrimidinyl]amino]-2-methyl-b enzenesulfonamide (Pazopanib), a novel and potent vascular endothelial growth factor receptor inhibitor. J Med Chem. 2008; 51:4632-4640.

38. Fulda S. The mechanism of necroptosis in normal and cancer cells. Cancer Biol Ther. 2013; 14:999-1004.

39. Steinhart L, Belz K, Fulda S. Smac mimetic and demethylating agents synergistically trigger cell death in acute 
myeloid leukemia cells and overcome apoptosis resistance by inducing necroptosis. Cell Death Dis. 2013; 4:e802.

40. Steinwascher S, Nugues AL, Schoeneberger H, Fulda S. Identification of a novel synergistic induction of cell death by Smac mimetic and HDAC inhibitors in acute myeloid leukemia cells. Cancer Lett. 2015; 366:32-43.

41. Gerges S, Rohde K, Fulda S. Cotreatment with Smac mimetics and demethylating agents induces both apoptotic and necroptotic cell death pathways in acute lymphoblastic leukemia cells. Cancer Lett. 2016; 375:127-132.

42. Rohde K, Kleinesudeik L, Roesler S, Lowe O, Heidler J, Schroder K, Wittig I, Drose S, Fulda S. A Bak-dependent mitochondrial amplification step contributes to Smac mimetic/glucocorticoid-induced necroptosis. Cell Death Differ. 2017; 24:83-97.

43. Nugues AL, El Bouazzati H, Hetuin D, Berthon C, Loyens A, Bertrand E, Jouy N, Idziorek T, Quesnel B. RIP3 is downregulated in human myeloid leukemia cells and modulates apoptosis and caspase-mediated p65/RelA cleavage. Cell Death Dis. 2014; 5:e1384.

44. Morgan MJ, Kim YS. The serine threonine kinase RIP3: lost and found. BMB Rep. 2015; 48:303-312.

45. Fukudo M, Ito T, Mizuno T, Shinsako K, Hatano E, Uemoto S, Kamba T, Yamasaki T, Ogawa O, Seno H, Chiba T, Matsubara K. Exposure-toxicity relationship of sorafenib in Japanese patients with renal cell carcinoma and hepatocellular carcinoma. Clin Pharmacokinet. 2014; 53:185-196.

46. Richly H, Henning BF, Kupsch P, Passarge K, Grubert M, Hilger RA, Christensen O, Brendel E, Schwartz B, Ludwig M, Flashar C, Voigtmann R, Scheulen ME, et al. Results of a Phase I trial of sorafenib (BAY 43-9006) in combination with doxorubicin in patients with refractory solid tumors. Ann Oncol. 2006; 17:866-873.

47. Juo P, Woo MS, Kuo CJ, Signorelli P, Biemann HP, Hannun YA, Blenis J. FADD is required for multiple signaling events downstream of the receptor Fas. Cell Growth Differ. 1999; 10:797-804.

48. Fulda S, Strauss G, Meyer E, Debatin KM. Functional CD95 ligand and CD95 death-inducing signaling complex in activation-induced cell death and doxorubicin-induced apoptosis in leukemic T cells. Blood. 2000; 95:301-308.

49. Fakler M, Loeder S, Vogler M, Schneider K, Jeremias I, Debatin KM, Fulda S. Small molecule XIAP inhibitors cooperate with TRAIL to induce apoptosis in childhood acute leukemia cells and overcome Bcl-2-mediated resistance. Blood. 2009; 113:1710-1722. 